\title{
THE EXERCISE OF JUDICIAL DISCRETION IN THE AWARD OF ALIMONY
}

\author{
EDWARD W. CoOEY*
}

Judicial discretion is probably nowhere more intimately connected with human relations, nor is it given freer rein, than in the field of domestic relations. Particularly is this true when applied to the question of alimony. The nature of judicial discretion, however, is such that the limits of its exercise cannot be fixed by definition, and it is the aim of this paper not to define, but to attempt to examine, the factors that tend to guide the discretion vested in the courts to determine the amount of alimony payable upon divorce.

The material presented here is, in the main, the result of a study of over one hundred cases in which the exercise of judicial discretion as to alimony was subjected to appellate review. The cases were taken from the reports of the decisions of appellate courts throughout the country during the year preceding this study, supplemented by representative cases of earlier date. Appellate cases cannot, of course, give an accurate picture of the situation as it exists in the trial courts, the real arena for the judicial discretion discussed here. Unfortunately, however, the records of the trial courts are almost inaccessible for study, and this necessitates the present approach.

But information as to the workings of the trial court in this field is not wholly lacking. The Institute of Law of Johns Hopkins University has made intensive studies of the divorce court in action in Ohio and Maryland. ${ }^{1}$ The Ohio study covered the period from July I, I930 to December 3I, 1930; the Maryland study covers all cases filed during I929 with disposition as of May I, I93I. These studies do not indicate the factors operative in the exercise of judicial discretion with respect to alimony, but they do reveal the results of the process in the large.

The study conducted in $\mathrm{Ohio}^{2}$ discloses that wives sought divorces and other "incidental relief"3 in 4195 actions for divorce and were accorded such relief in 4438 cases; while the husbands sought "incidental relief" in only 649 actions, they

* A.B., I936, Duke University. Student in the third-year class of the Duke University School of Law. Member of the editorial board of the Duke Bar Association Journal.

${ }^{7}$ Marshatr \& Max, The Drvorce Court-Maryland (I932), The Divorce Court-Ohio (i933).

"Marhiall \& May, The Divorce Court-Oho (1933) c. VI, "The Upshot of It All," pp. 320-342.

${ }^{3}$ In addition to alimony, this term may include custody of children, support money, property division, restoration of name, ctc. 
obtained it, nevertheless, in 747 cases. By table ${ }^{4}$ it is shown that where wives sought permanent alimony in a total of 1883 actions, they obtained it in $113 \mathrm{r}$. Of these 1883 actions, it was sought as the only incidental relief in 336 actions and obtained in 178 ; in 1547 actions, permanent alimony was sought in conjunction with other incidental relief, and here it was obtained in 953 cases.

Another table ${ }^{5}$ shows that out of 6586 actions, there were 69n known gross payments, ${ }^{6}$ and, of these, payments were awarded to the husband in 55 cases, to the wife in 635 , and to both in only one. Out of 1516 known periodic payments weekly awards were made to the wife in I049 and monthly awards in 430 . Where property rights were adjusted, out of 1227 known adjustments, 138 went to the husband only, 790 to the wife only, and 299 to both. Out of the total of 6586 actions, $69 \mathrm{r}$ or $10.5 \%$ resulted in decrees of a lump sum of money. ${ }^{7}$ In $91.9 \%$ of these cases, the award went to the wife. The median amount for these gross payments, for the state as a whole, was $\$ 386$.

Out of the periodic payments ${ }^{8}$ awarded in 1516 known actions, all but 37 were definitely payable to the wife. Of the remainder, 26 went to Juvenile Courts and II to third persons. ${ }^{9}$ Over two-thirds were weekly payments, and less than one-third were monthly payments. The median of weekly payments for the state was $\$ 7.6 \mathrm{r}$, and the median of monthly payments was $\$ 30$.

The authors point out that "the amount of the awarded periodic payment assumes its true significance only when stated in terms of the number of dependents involved. ... In the $145^{8}$ cases in which the number of dependents and the size of the periodic payments were both known, the average award per action was $\$ 9.04$, figured on a weekly basis, and this amounted to $\$ 3.42$ per week per person affected. When the award was made for the wife alone, she receivd \$r.66. But the larger the family, the less each person received. When there was a wife and one child, they secured $\$ 3.50$ apiece; if two children, $\$ 3.37$; if three children, $\$ 3.31$; four children, $\$ 2.39$; and five or more, $\$ 1.86 . " 10$ Thus the wife seems to get a child's share when there are children involved. ${ }^{11}$

Out of 2058 women having been awarded the custody of minor children, 1534 or $74.5 \%$ received an award of money or property. Of these, 1338 were plaintiffs and I 6 were defendants. Out of 4528 women who either had no minor children or were not awarded the custody of them, only 866 or $19.1 \%$ received alimony or property. The women with children "fared almost 4 times as well in obtaining money or

\footnotetext{
"Marsharl \& May, The Divorce Court-Ozno, Table VI, "Incidental Relief (other than counsel fees) Sought and Obtained in Divorce, Annulment, and Alimony Actions Granted in Ohio from July 1, 1930, to December 3x, r930," p. 323. " Id. at 328 .

"In some instances these gross payments include counsel fees, in some they are in fact in licu of alimony or support money, and in a few they are merely a lump sum award of alimony or support pendente lite in the payment of which the husband is in arrears." Id. at 331.

"Id. at 330 et seq.

8 This includes alimony, support money, and both. It does not include gross awards payable in instalments.

This type of payment it seems is almost exclusively awarded to the wife.

${ }^{20}$ Marshall \& May, The Divorce Court-Oho 337. See also, Chart VI at 339.

${ }^{11}$ For similar statistics as to Maryland, see Marshalz \& May, The Divorce Court-Maryand 314.
} 
property awards as did women without children."12 Hence although the wife's share decreases according to the number of children involved, she is more apt to receive an award because there are children involved. It is also pointed out that, in cases wherein children were concerned, the awards were much more likely to be continuing awards reaching into the future.

The Maryland study shows practically the same findings. The authors say, "It [alimony] is the only type of incidental relief which is obtained less frequently than it is sought in the petitions. Sought a total of 453 times, it was obtained but 218 times-well under one-half of the number of times sought. When asked for alone, it achieved little success indeed; out of I3I such requests, it was obtained but 23 times. ... In general a request for alimony fared best when it was evidently connected in some way with the welfare of the children."13

As to property adjustments, the Ohio study indicates that out of 6586 granted - actions, there were 1227 recorded instances of adjustment "without that adjustment being stated in financial terms."14 This was nearly one-fifth of the granted actions. The husband was the beneficiary in about one-tenth of these cases; the wife, in about two-thirds; and in about one-fourth of the cases both husband and wife received awards of property. It is pointed out that the fact that the wives fare so well in property adjustments should not be surprising. "Wives file the bulk of the petitions, and most petitions are not answered; in such situations household property, for example, is quite likely to be awarded to the wife."15

Although these studies do not provide information on the point, it may be surmised that among persons of wealth settlement of the financial matters attendant upon divorce is more frequently effected out of court than by decree. Where the property at stake is large, reluctance to rely on judicial discretion in its disposition is to be expected if amicable adjustment is at all possible.

Before turning to the cases reviewing judicial discretion, it should be pointed out that the word "alimony" as it will be used hereafter may include not only the more or less common continuing periodic payments, but also awards of gross sums and awards of property. Since the purpose of the investigation is to bring to light the factors in the judicial process behind the award, this broad use of the word will tend to give a more comprehensive picture. Separate maintenance and support for children, since they give rise to special problems without the scope of this symposium, will be considered, if at all, only incidentally.

As to types, alimony can be allowed on a temporary or permanent basis. There are two kinds of permanent alimony: that rendered on a decree of divorce from bed and board ( $a$ mensa et thoro) and that rendered on a decree from the bonds of matrimony (a vinculo matrimonii), but, since the cases seem to indicate that the factors involved in both categories are essentially the same, this distinction will not be

\footnotetext{
${ }^{12}$ Marshalt \& Max, The Divorce Court-Ohto 340.

${ }^{23}$ Marshati \& Max, The Divorce Court-Maryland $3 \times x$.

14 Marshail \& May, The Divorce Court-Oho 327 et seq.

${ }^{15} \mathrm{Id}$. at 329.
} 
observed in the treatment of permanent alimony. Since temporary alimony (alimony pendente lite) is not as significant as permanent alimony, it will be treated only generally.

Alimony has been described as, "an allowance which a husband, or former husband, may be forced to pay to his wife or former wife, who is living legally separated from him, for her maintenance," 18 or "an incident of marriage based on the duty of the husband to support his wife. It signifies not a portion of his estate but an allowance adjudged against him for her sustenance according to his means and their condition in life during their separation ... the controlling element is his compulsory contribution for her support and maintenance under obligations of the marriage contract."17 And again, "that provision which the law makes for the support of the wife or of her who was the wife, out of the estate of the husband after separation, in lieu of his common law obligation to support her as wife if they should have continued living together."18 Such definitions, however, mean very little unless they are considered in the light of a particular factual background.

Temporary alimony, as its name indicates, is only an ad interim provision for the support of the wife until the final determination of the divorce suit, ${ }^{19}$ or an award to give the wife the means of defending ${ }^{20}$ or prosecuting ${ }^{21}$ the suit, or both. Some cases indicate that it is given as a matter of right, ${ }^{22}$ while certain statutes place the question of an award in the discretion of the trial judge. ${ }^{23}$ The determination of the amount is in the discretion of the trial judge, ${ }^{24}$ and a wide latitude exists in the application of this discretion. Thus, where a wife was suing, it was held to be no abuse of discretion to award $\$ 4000$ as alimony pendente lite where the husband was worth from $\$ 80,000$ to $\$ 100,000$ and had an annual income of from $\$ 8,000$ to $\$ 10,000$, though the court pointed out that the award was a large one for temporary alimony. ${ }^{25}$ But in another case, in a suit by the husband, the court held that an award of $\$ 350$ for temporary alimony accruing since marriage, and $\$ 25$ a month pending the outcome of the suit, plus $\$ 300$ for counsel fees, where the husband was without a profession, trade, or a business, owned no property and had tried to find work but failed, was "so grossly excessive as almost to shock the moral sense."

The courts speak of the factors involved here in much the same language as they

${ }^{16}$ Bowen v. Bowen, I82 Okla. II4, 76 P. (2d) 900, 902 (I938).

${ }^{17}$ Ritzer v. Ritzer, 243 Mich. 406, 220 N. W. 812, 814 (1928).

${ }^{18}$ Muir v. Muir, I33 Ky. I25, 92 S. W. 314, 316 (Ig06).

${ }^{20}$ Duss v. Duss, 92 Fla. ro81, III So. 382 (1927).

${ }^{20} \mathrm{La}$ Fitte v. La Fitte, I7I Ga. 404, I55 S. E. 521 (1930). See also Note (1854) 60 Am. Dec. 676.

${ }^{21}$ Snyder v. Snyder, $159 \mathrm{Md} .39 \mathrm{I}, 150$ Atl. 873 (1930).

22 Ex parte Harris, 228 Ala. 88, 153 So. 449 (1934).

${ }^{23}$ See MD. CoDe ANN. (x935 Supp.) art. 16, \$16a: "In all cases where alimony or alimony pendente lite and counsel fees are claimed, the court shall not award such alimony or counsel fees unless it shall appear from the evidence that the wife's income is insufficient to care for her needs." See also Gs. Cons (r933) $\$ 30-203$.

${ }_{24}$ Bardin v. Bardin, 4 S. D. 305,56, N. W. 1069 (1893); Stalings v. Stalings, 127 Ga. 464,56 S. E. 469 (1907); Mulhall v. Mulhall, I20 Md. 22, 87 Atl. 490 (1913).

${ }_{25}$ Moore v. Moore, 130 N. C. 333,4 r S. E. 943 (1902).

${ }^{20}$ Culpepper v. Culpepper, 98 Ga. 304, 25 S. E. 443 (1896). 
do when considering the problem of permanent alimony, ${ }^{27}$ that is: financial condition of the parties, conduct, social status, age, health and others. The main emphasis, however, seems to be on the financial situation. ${ }^{28}$ This seems logical since the award is only a temporary arrangement and is mainly directed to the necessities of the wife.

In the cases concerning permanent alimony, repeatedly there appears the statement that its amount rests largely in the discretion of the trial judge. ${ }^{29}$ This is true even under statutes fixing the maximum amount which may be decreed. ${ }^{30}$ The statutory provisions, however, are not considered in this paper. ${ }^{31}$

The vesting of discretionary power in the trial judge does not mean that his discretion is absolute or uncontrolled. If an appeal is taken from his ruling, the appellate court will review it in the light of the facts appearing in the record and determine whether the discretionary power has been abused, i. e., whether its exercise appears to the appellate court to be arbitrary or unreasonable. Through their opinions reviewing discretionary action, the appellate courts have the opportunity not only to rectify injustices in the cases under review, but also to develop standards for future judicial action by stating the factors which should guide the trial judge in the exercise of his discretion.

What has in actuality motivated the trial judge will seldom be disclosed in the appellate opinion, nor, indeed, will the basis of the appellate court's action always be fully presented. What the opinion makes available is the set of factors and reasons which the court considered proper to employ in support of its decision. Rarely disclosed in the opinion will be the personal beliefs and biases of its author toward the marriage relation, divorce, and alimony itself, although it seems inevitable that such considerations must form the "inarticulate major premise" of many decisions in this field.

Among all the factors, ${ }^{32}$ perhaps the most important is the financial condition of the parties. This is necessarily so since the primary end to be achieved is the support of the former wife. ${ }^{33}$ It is logical, then, that where the wife's separate estate is sufficient to enable her to live in the manner to which she has been accustomed, no alimony will be allowed. ${ }^{34}$ In at least two jurisdictions, however, it is held that the

\footnotetext{
${ }^{37}$ Heilbron v. Heilbron, r58 Pa. 297, 27 Atl. 967 (I893); Fountain v. Fountain, 80 Ark. 48r, 97 S. W. 656 (rgo6); Day v. Day, I2 Idaho 556, 86 Pac. 53 I (1906); Brandenburg v. Brandenburg, $246 \mathrm{Ky}$. 546, 55 S. W. (2d) 351 (1932). $\quad{ }^{28}$ Ex parte Whithead, 179 Ala. 652, 60 S. 924 (1913).

20 White v. White, 73 Cal. ro5, I4 Pac. 393 (I887); Muir v. Muir, I33 Ky. I25, 92 S. W. 3 I 4 (xg06); Deeds v. Deeds, 108 Kan. 770, I96 Pac. I109 (r921); Fairbanks v. Fairbanks, I69 Md. 212, I8I Atl. 233 (1935); Rodgers v. Rodgers, 102 Colo. 94, 76 P. (2d) 1104 (1938).

${ }^{30}$ See Mrnn. Stat. (Mason, 1927) $\$ 8692 ;$ Pa. Stat. (Purdon, 1930) tit. $23, \S 47$.

${ }^{31}$ See Vernier, The Historical Background of Alimony Law and Its Present Statutory Structure, supra p. 201 et seq.

${ }^{32}$ For text treatments of these factors, see 2 Schouler, Drvorce, SEParation and Domistic Relations

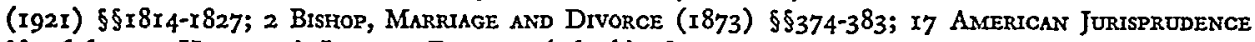
\$596-603; IO HaLsBuRY's Laws OF ENGLAND (2d ed.) 784.

ss 'It is a well-settled principle that, in the absence of a special statute providing therefor, a husband is not entitled to permanent alimony in a suit for divorce." Note (I923) 24 A. L. R. 49 I.

34 Thompson v. Thompson, 79 Mich. 124, 44 N. W. 424 (1898); Cottrell v. Cottrell, 24 Ky. L. Rep. 2417,74 S. W. 227 (I903); Wilkins v. Wilkins, 84 Neb. 206, 120 N. W. 907 (I909). See also MD. CoDE ANN. (1935 Supp.) art. \$16a. cited supra note 23; KY. STAт. (Carroll, I936) \$2212; I9 C. J. 258.
} 
wife's estate and capacity to earn is not to be considered. ${ }^{35}$ Thus in one case under this minority rule, where it was shown that the wife owned a $\$ 300$ lot and a half interest in an automobile worth $\$ 1000$ and that she had an income of about $\$$ r28 per month, the court said, "Ordinarily the wife's estate and capacity to earn money ... are not to be considered." 36

When the husband has an estate, and especially where lump-sum alimony is sought, the extent of that estate is the factor of primary interest. ${ }^{37}$ In one case where the suit was by the wife, and alimony was denied in the lower court, the appellate court focused its attention on the husband's estate and found that it consisted of a farm for which he had refused $\$ 3$ roo, four or five horses and other personal property, a one-third interest in his father's estate, subject to a life estate in his mother who was then seventy-five, and that the father's estate was worth about $\$ 4000$. The court then held that the wife was entitled to alimony of $\$ 1000^{38}$

In considering the estate of the husband, it is thought pertinent to inquire whether or not the wife helped in the accumulation of it. ${ }^{32}$ It was held in one case that a wife divorced for the fault of the husband was entitled to alimony of $\$ 2250$, where they had no children and the husband had about $\$ 5000$, which the wife had helped him to earn; ${ }^{40}$ but, in another, a wife who had not contributed to the estate was held only entitled to alimony of $\$ 5000$ although her husband's estate was valued at about $\$ 75,000 .{ }^{41}$

Another legitimate factor to consider is the reasonable future expectancy of the husband. ${ }^{42}$ Hence the court may take into account the husband's interest in his father's estate which will come to him on the death of his mother. ${ }^{43}$

Where the husband has no estate or where periodic payments are sought, the husband's income or earning capacity is accorded emphasis. ${ }^{44}$ It was said in one case, "in determining the matter of alimony to be awarded, the court may take into consideration not only the husband's property and income, but also his capacity to earn money from personal attention to business. If it were otherwise a husband by de-

\footnotetext{
${ }^{35}$ Speery v. Speery, 80 W. Va. 142, 92 S. E. 574 (r917); Kittle v. Kittle, 86 W. Va. 46, roz S. E. 799 (1920); Cralle v. Cralle, 84 Va. 198, 6 S. E. 12 ( 1887 ).

${ }^{38}$ Dayton v. Dayton, I09 W. Va. 759, 556 S. E. 105 (1930).

${ }^{37}$ Hall v. Hall, 25 Ky. L. Rep. 1304, 77 S. W. 668 (1903); Carter v. Carter, 140 Ky. 228, r30 S. W. Ir02 (Igro); Reynolds v. Reynolds, 68 W. Va. 15, 69 S. E. 38 r (19ro).

88 Thompson v. Thompson, 27 Ky. L. Rep. 516, 85 S. W. 730 (1905).

${ }^{30}$ Zimmerman v. Zimmerman, 59 Neb. 80,80 N. W. 643 (r899); Blair v. Blair, 40 Utah 306, 12x Pac. Ig (Igr2); Máan v. Mason, 233 S. W. 263 (Mo. App. I92I).

${ }^{10}$ Vey v. Vey, 150 lowa 166,129 N. W. 801 (19rr).

${ }^{41}$ Miller v. Miller, $229 \mathrm{Ky} .436$, 77 S. W. (2d) 412 (1929).

${ }^{12}$ Muir v. Muir, $133 \mathrm{Ky} .125,92$ S. W. 314 (1906); Anderson v. Anderson, 152 Ky. 773, 154 S. W. I (rgr3); Green v. Green, I52 Ky. 486, 153 S. W. 775 (I9r3); Plankers v. Plankers, I72 Minn. 464, 217 N. W. 488 (1928). See also Note (1906) 4 L. R. A. (N. S.) 909.

"3 Johnson v. Johnson, 36 Ill. App. 152 (1890). In Ramsey v. Ramsey, I25 Miss. 185,87 So. 491 (1921), the husband had no property but the court awarded alimony in respect to his future earnings. Contra: Feigley v. Feigley, $7 \mathrm{Md}$. 537, 6r Am. Dec. 376 (1855): "Where there is no estate there can therefore be no alimony."

${ }^{*}$ Ex parte Spencer, 83 Cal. 460, 23 Pac. 395 (1890); Hedrick v. Hedrick r28 Ind. 522, 26 N. E. 768 (1891); Hooper v. Hooper, 102 Wis. 598, 78 N. W. 753 (1899); Reed v. Reed, 182 Okla. 149, 77 P. (2d) 30 (1938). See also Note (1920) 6 A. L. R. I95.
} 
liberate intent or disinclination to work might defeat or avoid his marital obligation of support." ${ }^{45}$ That the absence of a present capacity to support the wife is not controlling, is shown in another case where the Chancellor, commenting orally, said, "I think it is right that the sum allowed for alimony should be made so low that any healthy man, irrespective of a favorable engagement, should be able to earn it." 46 One court has refused, in determining the husband's income, to include in it returns from gambling. ${ }^{47}$ Pensions, however, can be considered. ${ }^{48}$

What of the consideration of the indebtedness of the husband? Since the amount of alimony to be set should not weigh too heavily on the husband, it seems only logical that his debts should be a factor. This was pointed out in one case, the court saying, "The husband is not relieved of his duty to his wife by the fact that he owes debts, but his indebtedness must be considered in fixing the amount of alimony."

Can the parties determine between themselves the amount of alimony? Two sorts of agreements are possible, ante nuptial and post nuptial. The main consideration in determining the validity of ante nuptial agreements seems to be whether or not they are fair to the wife, but any ante nuptial agreement which tends to induce or encourage separation or divorce is against public policy and hence void. ${ }^{50}$ For example, an ante nuptial contract in which it is agreed not to ask for alimony or counsel fees in case of separation is invalid. ${ }^{51}$ Post nuptial agreements may be either property settlements or attempts to regulate support. The court will tend to look closely for evidence of collusion, ${ }^{52}$ and, if such is found or if the agreement is such as would tend to encourage dissolution of the marital bonds, it will be treated as void. ${ }^{53}$ Agreements by the husband to provide for his wife in the event of such subsequent misconduct on his part as would justify a separation have been generally upheld, ${ }^{54}$ and the right of the parties in a divorce suit to settle their property rights outside of court has been recognized, and this agreement if entirely fair will not be disturbed. ${ }^{55}$

Since alimony is essentially for the support of the wife, it seems illogical, in a way, that the idea of punishment should enter into the court's reasoning, and yet, the guilt of the divorced spouse becomes a factor tending to augment the award. This guilt

${ }^{45}$ Robins v. Robins, 106 N. J. Eq. I96, 150 Atl. 340, 34 I (r930).

${ }^{40}$ Furth v. Furth, 39 Atl. 128, 129 (N. J. Eq. I898).

${ }^{4}$ King v. King, 79 Neb. 852 , II3 N. W. 538 (1907).

${ }^{48}$ Hedrick v. Hedrick, 128 Ind. 522, 26 N. E. 768 (I89r); Tully v. Tully, 159 Mass. 9r, 34 N. E. 79 (1893); Bailey v. Bailey, 76 Vt. 264, 56 Atl. 1014 (1903).

${ }^{\circ}$ Young v. Young, 323 Ill. 608 , I54 N. E. 405,408 (1926). Alimony is a debt of the husband preferred over his other debts only as to remedy and the fact that it is not discharged by bankruptcy. For a discussion of the rights of the wife's creditors to reach her alimony, see (I936) 4 Duke BAR Ass'N J. 94.

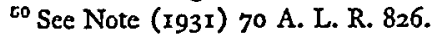

${ }^{41}$ Hilbert v. Hilbert, I68 Md. 364, 177 Atl. 914 (1935).

${ }^{62}$ See Note (19r9) 2 A. L. R. 699.

${ }^{53}$ See Note (19:3) 44 L. R. A. (N. S.) 379. For example, an agreement between husband and wife whereby he was to pay a certain sum to her and also to put notes in escrow to be delivered to her when she should have obtained a divorce was held to be void, Adams v. Adams, 25 Minn. 72 (1878).

tsee Note (I9IO) 23 L. R. A. (N. S.) 880.

Es Young v. Thompson, 220 Mo. App. 1266,290 S. W. 85 (1927). For a discussion of the right of the wife to relief against a transfer made in fraud of her right to support, see Note (rg09) I 8 L. R. A. (N. S.) II 47. 
is what the courts mean when they speak of the "conduct of the parties." Thus, in Muir v. Muir, ${ }^{56}$ the court gave considerable weight to the fact that the husband had infected his wife with a venereal disease. In another case, ${ }^{57}$ the parties were engaged in a small business to which the wife had contributed part of the original capital. The husband had infected the wife with a venereal disease, but the suit was, at his instance, based on the alleged misconduct of a step-daughter. On cross-complaint, the wife was awarded a divorce and alimony in the form of: a five-room house which rented for \$18 per month, other property renting for \$20 per month, two cars worth about $\$ 500$, and the business and equipment itself. The husband was awarded property valued at about $\$ 75^{\circ}$.

Where the wife is the guilty party and the husband obtains the divorce, permanent alimony will not as a general rule be awarded. ${ }^{58}$ Thus it has been said that where a wife is divorced for her cruelty, ${ }^{59}$ adultery, ${ }^{60}$ or desertion, ${ }^{61}$ she is not entitled to alimony. Where there is partial fault on both sides a sort of weighing process goes on. In one case where the husband voluntarily abandoned his wife, the fact that her "ill temper" and "mean disposition" drove him away from home was considered in setting the proper amount of alimony. ${ }^{82}$ In another case, the court, granting the husband a divorce because of the "cruel and inhuman treatment" by the wife, "consisting of a long succession of relatively trivial incidents," held that an award of $\$ 1200$ a month out of the husband's annual income of about $\$ 180,000$ was not inadequate. ${ }^{63}$

In the cases examined, there seems little or no tendency to inquire into the circumstances leading to the marriage. An exception appears in the case of Whithorn $v$. Whithorn. The wife was suing the husband for divorce and alimony and the husband had filed a cross-petition. The trial court apparently arrived at the conclusion that the marriage was one of convenience only in this manner, "In sitting here yesterday and looking at the defendant in this case, if there is anything that would make one come to the conclusion that we have descended from monkeys, looking at this man would make you think of it. $\mathrm{He}$ had the appearance and countenance of a gorilla. I would hate to be led to the belief that the plaintiff in this case married this man loving him or because he was attractive." ${ }^{4}$ The appellate court in commenting on this procedure indicated a certain sense of humor when it said, "It is extremely

${ }^{50}{ }_{133} \mathrm{Ky} .125,92 \mathrm{~S}$. W. 314 (1906). See also Gussman v. Gussman, r40 Ind. 433, 39 N. E. 918 (1895); Tuttle v. Tuttle, 26 S. D. 545, 128 N. W. 695 (1910); Smith v. Smith, 167 Ga. 98 , 145 S. E. 63 (1928).

${ }^{57}$ Tway v. Tway, 280 N. W. 910 (Neb. 1938).

${ }^{58}$ Holman v. Holman, 155 Ky. 493, 559 S. W. 937 (I913); McKannay v. McKannay, 68 Cal. App. 70I, 230 Pac. 214 (I924); Grush v. Grush, 9o Mont. 381, 3 P. (2d) 402 (193I); In re McKenna, II6 Cal. App. 232, 2 P. (2d) 429 (193I). See also Note (1933) 82 A. L. R. 539.

${ }^{20}$ McKannay v. McKannay, 68 Cal. App. 701, 230 Pac. 214 (r924).

${ }^{60}$ Beeler v. Beeler, x9 Ky. L. Rep. 1936, 44 S. W. 136 (r898); Hulette v. Hulette, 152 Miss. 476, I19 So. 581 (1928). (I93I).

${ }^{61}$ Coffec v. Coffec, 145 Miss. 872, 1 I I So. 377 (1927); Grush v. Grush, 90 Mont. 38I, 3 P. (2d) 402

${ }^{\circ 2}$ Jones v. Jones, 95 Ala. 443, II So. II (1892).

${ }^{63}$ Cudahay v. Cudahay, 217 Wis. 355,258 N. W. 168 (1935).

ot 169 Okla. 374,36 P. (2d) 943,945 (1934). 
unsafe to hazard a guess upon such appearance, since many marriages where wealth is not concerned would on the application of a similar assumption become impossible of explanation." 65

In addition to these factors, the social status, ${ }^{66}$ age and health, ${ }^{67}$ and duration of the marriage ${ }^{68}$ are almost invariably listed as factors to be considered, but the absence of discussion of these factors in the opinions precludes resort to illustration.

The desire for a more certain basis of decision than the factors heretofore enumerated, together with the judicial tendency to seek for an analogy, has led some courts and some statutes to recognize what may be called a "Rule of Dower." For example, the Pennsylvania statute reads, "In cases of divorce from bed and board, the court may allow the wife such alimony as her husband's circumstances will admit of but the same shall not exceed the third part of the annual profit or income of his estate or his occupation and labor." 69 In regard to the use of specific proportions in the cases, it has been pointed out that if the cases are examined, it will be found that what is considered a specific proportion is merely that amount which under the circumstances is reasonable. ${ }^{70}$ That is probably true, but nevertheless some cases seem to recognize the rule. For example, the court in Muir v. Muir, says, "Where she is entitled to alimony, it would seem improper to give her less, in any event, than which her dower interest in her husband's estate would have been."71 In another case it was stated, "It is also a general rule for the guidance of the trial court though not mandatory, that in awarding alimony to an innocent and injured wife, as part of a divorce decree, the wife should receive such sum as would leave her in as good condition as a surviving wife upon her husband's death."72 And in still another case, the fact that the divorce cut off the wife's inchoate right of dower was said to be an element to be considered. ${ }^{73}$ The New Jersey court said in one case, "No standard can be set up . . . but it is usually about one-third of the husband's income. ${ }^{74}$ Yet in a later case, the same court said that, despite repeated urgings by the Bar that alimony for the support of the wife be set at one-third of the husband's income, such was not the rule in New Jersey. ${ }^{\mathbf{7 5}}$

All too generally the appellate courts are content to discharge their function of affording guidance to the trial courts by the recital of formulae like the following. "In fixing the amount of permanent alimony, all evidence must be considered relating to the respective ages of the parties, duration of and conduct during marriage, the station in life, circumstances, and necessities of each, as well as their health and

os ybid.

${ }^{00}$ Hooper v. Hooper, 102 Wis. 598,78 N. W. 753 (1899); Young v. Young, 323 Ill. 608, 554 N. E. 405 (1926); Topor v. Topor, 287 Mass. 473,192 N. E. 53 (1934).

${ }^{\circ 7}$ Roberts v. Roberts, 160 Md. 513, 154 Atl. 95 (1931); Tway v. Tway, 280 N. W. 910 (Neb. 1938); Fowler v. Fowler, 158 Ore. 586,76 P. (2d) 1132 (1938).

${ }^{88}$ Zimmerman v. Zimmerman, 59 Neb. 80, 80 N. W. 643 (1899); Collins v. Collins, 182 Okla. 246, 77 P. (2d) 74 (1938).

${ }^{\circ 0}$ PA. Stat. (Purdon, 1930) tit. 23, \$47. See also Minn. Stat. (Mason, 1927) $\$ 8602$.

${ }^{70}$ Note (1913) 44 L. R. A. (N. S.) $998 . \quad{ }_{71} 133$ Ky. 125, 92 S. W. 314, 317 (1906).

${ }^{72}$ Dissette v. Dissette, 208 Ind. 567 , x96 N. E. 684,692 (r935).

${ }^{73}$ Born v. Born, 237 Mich. 323, 211 N. W. 657 (1927).

${ }^{74}$ Dietrick v. Dietrick, 88 N. J. Eq. 560, 102 Atl. 242, 243 (I918).

${ }^{75}$ Williams v. Williams, I2 N. J. Misc. 641, I74 Atl. 423 (1934). 
physical condition." $\mathrm{Or}$, in a similar vein, "In determining the amount, regard should be had to a number of circumstances. Among these are the amount of the estate of the husband, his income, his age and earning capacity, and the age, health, station and separate estate of the wife." 77

Almost every case in which alimony is granted contains language similar to the above. ${ }^{78}$ Exception cannot be taken to such generalities, but unless their application to the facts of specific cases is known, appraisal of the actual utilization of the factors recited is impossible.

A very recurrent type of case is one in which the court describes its methodology at the outset of the opinion in impressive terms, such as, "The amount is not fixed solely with regard on the one hand to the actual needs of the wife, nor, on the other, to the husband's actual means. There should be taken into account the physical condition and the social position of the parties, the husband's property and income ... and also the separate property and income of the wife,"70 and then proceeds to dispose of the case in a single page.

In another case the court said, "their mutual troubles, criminations, and recriminations are told in a record of more than 800 pages. It is unnecessary to discuss this evidence in detail. It is sufficient to say that it exhibits a most lamentable condition of affairs, and fully sustains the learned chancellor in his judgment separating the parties." ${ }^{\circ 0}$ The wife was awarded a divorce a mensa et thoro and alimony of $\$ 150$ per annum but how much of these 800 pages of record related to the question of alimony is a mere conjecture, for the appellate court disposed of the case in less than two columns of the Reporter.

It is easy to sympathize with the attitude of the court here, for the inclination to conceal those facts which are essentially private is natural enough. Yet the practice leaves uncertain whether there has been a lack of thorough investigation on the part of the trial court or only a lack of thorough reporting on the part of the appellate court. $^{81}$ If the lack of evidence in the appellate reports, however, can be traced to alimony having been awarded in the lower courts on insufficient evidence, then one might be justified in saying that Mr. Husband was merely measured by the "Chancellor's Foot." 82

${ }^{70}$ Felton v. Felton, I3I Neb. 488,268 N. W. 34 r, 343 (1936).

${ }^{77}$ Heard v. Heard, 116 Conn. 632, 166 Atl. 67, 68 (1933).

${ }^{78}$ See, e. g., Dayton v. Dayton, 109 W. Va. 759, 156 S. E. 105 (1930); Lonabaugh v. Lonabaugh, 46 Wyo. 23, 22 P. (2d) 199 (x933); Cary v. Cary, I12 Conn. 256, 152 Atl. 302 (1930); Dresser v. Dresser, I64 Okla. 92, 22 P. (2d) ror2 (1933); Metzger v. Metzger, 278 N. W. 187 (Iowa, 1938).

${ }^{70}$ Dietrick v. Dietrick, 88 N. J. Eq. 560 , 103 Atl. 242, 243 (I918).

${ }^{80}$ Hughbanks v. Hughbanks, 25 Ky. L. Rep. 849, 76 S. W. 355 (rgo3).

${ }^{81}$ Only occasionally does one find a case in which the economic background of the parties has been fully presented. Wells v. Wells, II7 S. W. (2d) 700 (Mo. App. I938), is such a case. The property owned by the husband was noted, his equity in it and the loans on it; his stocks, salary, bonuses and annual income were estimated. The financial background of the wife was also investigated and her equity in the property, her income and her previous experience as a wage earner were considered. The husband's annual income was found to be approximately $\$ \times 6,500$ and the wife, granted a divorce on her cross-bill, was, on appeal, awarded alimony of $\$ 300$ per month together with custody of a minor child for whose support \$100 per month was allowed.

82 "Equity is a roguish thing, for law wee have a-measure, know what to trust too. Equity is accord. ing to ye conscience of him yt is Chancellor, and as yt is larger or narrower soe is equity. Tis all one as 
Frequent resort to presumptions by the appellate courts lends strength to this suspicion. Typical of the cases are statements such as, "deference is due the decree of the chancellor who is presumed to know the needs of the wife and the ability and resourcefulness of the husband," 83 or, "It is to be presumed that all the facts in existence at the time of the trial, bearing on the alimony ... a and defendant's ability to pay, were presented to the court." ${ }^{\text {"84 }}$ Whether the appellate court is generally justified in thus giving the benefit of the doubt to the trial court may be questioned.

In any event, the instances are rare wherein the appellate court finds the evidence as to alimony insufficient and reverses the decree of the lower court. In one case the court said, "We have in the statement of material facts the bare finding of the wife's adulterous conduct with no finding as to the many circumstances which should at least be given sole consideration in determining whether an award in the nature of alimony should be made and in fixing its amount." $\$ 55$ In another, alimony of $\$ 160$ per month had been awarded to the wife on the basis of an income of about $\$ 6,500$ a year from an estate, the title to which was in question at the time of the award. The husband denied that title was in him, which if true would have left him with no income. The court said, "On the record presented there is therefore no factual basis for the award made... . There is no prescribed standard for the admeasurement of alimony ... but the factors which enter into and serve as a basis for the determination must be proved by legal evidence. And the burden of proof is upon the wife." 86 And yet in both of these cases, deficient as they were, alimony awards had been made in the lower courts.

Not only are reversals for inadequacy of evidence unusual but reversals for all causes constitute an exceedingly low proportion of the cases appealed. Seldom is the trial court found to have abused its discretion. In one instance, however, where the wife, who was the complainant, was worth about $\$ 170,000$ and the delinquent husband about $\$ 160,000$, an award of $\$ 75,000$, being in lieu of dower and including an allowance for the support and education of two minor children, was reduced to $\$ 30,000 .^{87}$ In another case, where the husband made only $\$ 75$ per month and owned nonproductive property valued at $\$ 200$ and where the wife had property returning her $\$ 100$ per year, an award of $\$ 75$ per month was reduced to $\$ 300^{88}$ The appellate court may also increase the award. Thus in one case where the husband was worth about $\$ 5000$ and this was mostly accumulated during the marriage with the material help of the wife, an award of $\$ 1000$ was held to be inadequate and the amount was raised to $\$ 2250 .{ }^{82}$ In another case, an award of $\$ 800$ was raised to $\$ 1500$ where both parties

\footnotetext{
if they should make ye standard for ye measure wee call a foot, to be ye Chancellors foot; what an uncertain measure would this be; One Chancellor ha's a long foot, another a short foot, a third an indifferent foot; tis ye same thing in ye Chancellors conscience." TABLE TAIK of JoHn SELden (Pollock's ed. I934) 43 .

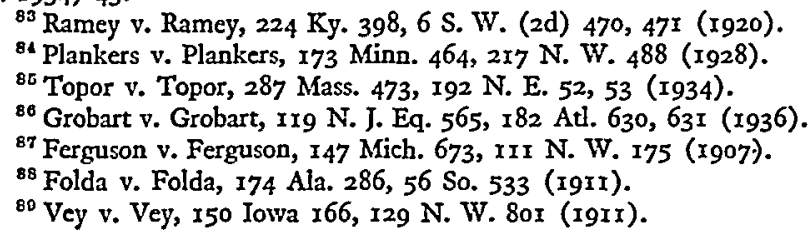


were over sixty and where the husband was worth about $\$ 6200$ and the wife was worth only about $\$ \mathrm{r}_{300} .^{90}$

The infrequency of reversals testifies to the reality of the discretionary power allowed the trial judge; reversals for abuse of discretion are far more frequent in many other branches of the law. Infrequency of reversals also suggests a partial explanation of the brevity of opinions in alimony appeals: an appellate court is under more pressure to develop at length its reasons for reversal than for affirmance. ${ }^{01}$

The number of divorce cases that are taken to the appellate courts on appeal comprises but a minute fraction of the total number of cases heard in the trial courts. Of the cases appealed only a small proportion are reversed. On its face, this situation might seem to indicate a nearly perfect functioning of the divorce courts. But the statistics compiled in the Ohio and Maryland studies, set forth earlier in this article, suggest another explanation for the paucity of appeals. The average award of alimony is small, and, if this is an indication of the financial condition of the litigants, it is apparent that few can well afford to carry appeals to the appellate courts. This means that the operation of the trial courts is not often subject to check. Not only does this fact call for caution in assuming their proper functioning, but it enhances the importance of such guidance as the appellate courts can give in those cases that come before them.

As an element in guiding the trial court's discretion, a more businesslike approach to the financial situation of the parties, on the part of the appellate court, might materially aid and influence the handling of this type of case by both the trial court and counsel. If, instead of a random selection of items relating to the financial status of the parties, their assets and liabilities were fully and systematically presented in the opinion, the decision with reference to the award would be far more illuminating. The importance of adequate data as a basis for decision would be given the emphasis it deserves, and the example, if heeded by counsel, might render it necessary less often for the appellate court to indulge a presumption that sufficient facts were brought to the attention of the trial court. Moreover, a fuller development and discussion of the non-financial factors in the light of the facts available would make more understandable the disposition of the case. It is not enough to know that, say, age or social condition is a factor in the decision; it is important to know why and to what extent.

Consideration might be given to the adoption of some standard in the form of a certain proportion of the estate or income of the husband to serve as a guide only and to be deviated from as the facts suggest. ${ }^{02}$ This would tend to advance predictability and to discourage capricious action. The danger inherent in this suggestion is that which is inherent in any mechanical device: the tendency to adhere blindly to the standard. If this were to develop, the element of flexibility, characteristic of judicial discretion and especially desirable in alimony cases, would, of course, be lost.

${ }^{\circ 0}$ Lawler v. Lawler, 157 Mich. 107, I21 N. W. 254 (1909).

${ }^{01}$ Especially is this true where the case is remanded to the lower court for further proceedings since it is then that the need for affording guidance to the trial judge is most evident.

${ }^{02}$ Other approaches to the problem of providing support for the divorced wife might eliminate the need for recourse to judicial discretion. Thus, utilization of the insurance principle has been suggested in Bradway, Why Pay Alimony? (1937) 32 ILI. L. REv. 295. 